\title{
Why does your pain never get better? Stigma and coping mechanism in people with sickle cell disease
}

\author{
Por que sua dor nunca melhora? Estigma e enfrentamento de pessoas com doença falciforme \\ ¿Por qué tu dolor nunca mejora? Estigma y enfrentamiento de personas con enfermedad falciforme
}

Evanilda Souza de Santana Carvalho'
ORCID: 0000-0003-4564-0768

Jayanne Moreira Carneiro'

ORCID: 0000-0003-3961-7959

Aline Silva Gomes'

ORCID: 0000-0002-3012-6849

Katia Santana Freitas'

ORCID: 0000-0002-0491-6759

Coretta Melissa Jenerette" ORCID:0000-0002-9851-4768

'Universidade Estadual de Feira de Santana. Feira de Santana, Bahia, Brazil.

"University of South Carolina. Columbia, South Carolina, United States.

How to cite this article: Carvalho ESS, Carneiro JM, Gomes AS, Freitas KS, Jenerette $\mathrm{CM}$. Why does your pain never get better? Stigma and coping mechanism in people with sickle cell disease.

Rev Bras Enferm. 2021;74(3):e20200831.

https://doi.org/10.1590/0034-7167-2020-0831

Corresponding author:

Evanilda Souza de Santana Carvalho

E-mail: evasscarvalho@uefs.br

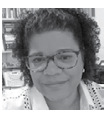

EDITOR IN CHIEF: Antonio José de Almeida Filho ASSOCIATE EDITOR: Mirtzy Reichembach

Submission: $07-21-2020$

Approval: 01-30-2021

\section{ABSTRACT}

Objectives: to analyze the characteristics of stigma in the interactions of people with pain and sickle cell disease and the coping strategies adopted. Methods: qualitative study, conducted in Bahia's reference units between January and July 2018. In-depth interviews were applied to 25 adults, followed by content analysis and interpretation in light of the Sociological Theory of Stigma. Results: four categories emerged from the data: Stigma in interactions with family members; Stigma in interactions with people in the general public; Stigma in interactions with health workers; and Strategies for coping with stigma. Final Considerations: in the participants' interactions, stigma produced discrediting pain reports, labeling and stereotyping, blaming patients for not improving their health, discrimination, racism, inadequate pain assessment, and delay in care. Coping included silencing, covering up, aggressive behavior, exposure to risk, reading religious texts and praises, and church attendance.

Descriptors: Sickle Cell Disease; Social Stigma; Pain; Nursing; Sickle Cell Anemia.

\section{RESUMO}

Objetivos: analisar as características do estigma nas interações de pessoas com dor e doença falciforme e as estratégias de enfrentamento adotadas. Métodos: estudo qualitativo, realizado em unidades de referência na Bahia, entre janeiro e julho de 2018. Entrevistas em profundidade foram aplicadas a 25 adultos, seguidas de análise de conteúdo e interpretação à luz da Teoria Sociológica do Estigma. Resultados: quatro categorias emergiram dos dados: Estigma nas interações com familiares; Estigma nas interações com pessoas do público geral; Estigma nas interações com os trabalhadores de saúde; e Estratégias de enfrentamento do estigma. Considerações Finais: nas interações dos participantes, o estigma provocava descrédito dos relatos de dor, atribuição de rótulos e estereótipos, culpabilização por não melhorarem a saúde, discriminação, racismo, avaliação inadequada da dor e demora no atendimento. $O$ enfrentamento incluiu silenciamento, encobrimento, comportamento agressivo, exposição ao risco, leitura de textos e de louvores religiosos e frequentação a igrejas.

Descritores: Anemia Falciforme; Estigma Social; Dor; Enfermagem; Hemoglobina Falciforme.

\section{RESUMEN}

Objetivos: analizar características del estigma en interacciones de personas con dolor y enfermedad falciforme y estrategias de enfrentamiento adoptadas. Métodos: estudio cualitativo, realizado en Bahia, entre enero y julio de 2018. Entrevistas en profundidad fueron aplicadas a 25 adultos, seguidas de análisis de contenido e interpretación a la luz de la Teoría Sociológica del Estigma. Resultados: cuatro categorías emergieron de los datos: Estigma en interacciones con familiares; Estigma en interacciones con personas del público general; Estigma en interacciones con los trabajadores de salud; y Estrategias de enfrentamiento del estigma. Consideraciones Finales: en las interacciones de los participantes, el estigma provocaba descrédito de los relatos de dolor, atribución de rótulos y estereotipos, culpabilización por no mejoraren la salud, discriminación, racismo, evaluación inadecuada del dolor y retraso en la atención. El enfrentamiento incluyó silenciamiento, encubrimiento, comportamiento agresivo, exposición al riesgo, lectura de textos y de himnos religiosos y frecuentación a iglesias. Descriptores: Anemia Falciforme; Estigma Social; Dolor; Enfermería; Hemoglobina Falciforme. 


\section{INTRODUCTION}

Pain occupies a central position in the experience of people with sickle cell disease (SCD). Since childhood, they have acute complications accompanied by pain, such as dactylitis, splenic sequestration, acute chest syndrome, stroke, priapism, and bone infarction. Throughout life, pain may increase in frequency and intensity. Chronic complications of SCD, such as necrosis of bone extremities and leg ulcers, also produce painful events ${ }^{(1-3)}$. The pain crisis is the most common cause for emergency department admission, and its main complaints are pain, almost always generalized, but which can also be chest, head, abdominal, lower limbs, and leg ulcers ${ }^{(2-3)}$. The pain can be described as persistent, sharp, radiating, burning, tingling, electric shock, or numbness, among other types ${ }^{(1)}$.

In painful crises, for instance, situations of stigma associated with the complications of chronic illness can result in barriers in the care of the sick person and promote passivity and invisibility. All this contributes to the suffering not detected by health professionals, constituting an institutional discrimination that favors the delay in diagnosis and the non-inclusion of the patient in comprehensive care programs ${ }^{(1)}$.

In his "Social Theory of Stigma," Erving Goffman ${ }^{(4)}$ defends the existence of a deteriorated identity and establishes the difference between virtual social identity (what somebody expected the person should be) and real social identity (the one based on the attributes a person possesses). Stigma refers to a mark or personal attribute used to classify and depreciate an individual who possesses a specific characteristic judged as "abnormal" and "deviant" from the social standard. In this sense, stigma consists of a social classification based on socially accepted attributes as positive or negative. People with positive attributes fall into the category of "normal," and those linked to attributes considered negative fall into the category of "stigmatized"(4). This process of stigmatization does not reduce to a critical look at the person. It is an interactive process that disqualifies the person and tends to transform the victim into a culprit ${ }^{(4)}$, besides causing discrimination and social exclusion of greater or lesser severity ${ }^{(5-6)}$.

When related to health, stigma refers to a particular form of individuals' devaluation, judgment, or social disqualification based on a health-disease condition ${ }^{(7-8)}$. Its existence amplifies the suffering and the burden of the disease on patients and their families ${ }^{(7)}$.

People who experience stigma may adopt positive or negative coping strategies. Positive strategies contribute to health and well-being, feelings of esteem, and inclusion; negative strategies are those that harm health, encourage the adoption of unhealthy habits, deepen isolation, feelings of loneliness, and self-depreciation ${ }^{(9)}$.

Literature concerning SCD experience denounces the existence of stigma without addressing how it can express in the various interactions. The present study contributes to filling this gap by deepening the knowledge about this phenomenon's characteristics and raising reflections about the effects of stigma in care encounters. One question guided this study during its development: How do people with SCD experience and face stigma?

\section{OBJECTIVES}

To analyze the characteristics of stigma in the interactions of people with pain and SCD and the coping strategies.

\section{METHODS}

\section{Ethical aspects}

This study was approved by the Research Ethics Committee of the State University of Feira de Santana. During nursing consultations, people were invited to participate and received information about the objectives of the study. Those who accepted the conditions signed the Free and Informed Consent Form. The study maintained anonymity using the letter "I" (Interviewee"), followed by sequential numbering indicating the order of the interviews.

\section{Type of study}

Qualitative study, whose study design followed the recommendations of the Consolidated Criteria for Reporting Qualitative Research (COREQ) ${ }^{(10)}$.

\section{Study setting}

The study was conducted in Bahia's capital and interior, between January and July 2018, in two reference units that offer healthcare to people with SCD.

\section{Data source}

Researchers worked with SCD users in reference units where the study was carried out to produce the data. The selection of participants occurred by convenience. For those who agreed to participate, the inclusion criteria were: being an adult of both genders, assisted at the reference center, aged 18 years or older, diagnosed with SCD, and with a history of pain crises. The exclusion criterion was being in pain at the time of data collection.

\section{Collection and organization of data}

In the production of data, one of the authors conducted indepth interviews. These ${ }^{(11)}$ were guided by a script previously tested in a research pilot, based on questions related to the treatment received by people with SCD and the sharing of contexts that marked their experience with the service.

Also, they formulated open-ended questions during the interaction that was taking shape as the interview was taking place. Thus, they are subject to the unpredictability of the personal characteristics of the participant and the context, which allows for interference from the interviewer, the formulation of additional questions, reordering and clarification of questions, to deepen topics introduced by the interviewee ${ }^{(11)}$.

The interviews, guided by the script previously validated in a pilot test ${ }^{(10)}$, recorded the following guiding questions: "Tell me how people n general treat people with SCD," "Have you ever experienced any defining situation with these people? Tell me what happened". Similar questions about the interaction with family members and health care workers were also applied. The 
collection took place in a private environment, with only the participant and the interviewer present. The interviews, which lasted between 40 and 50 minutes, were recorded in MP3 format and then transcribed in full by the interviewer. Five procedural steps were adopted to reach theoretical saturation: raw data recording (primary sources); immersion in the data; a compilation of the individual analyses of each interview; thematic grouping; allocation of themes and types of statements in a table ${ }^{(12)}$.

\section{Data analysis}

All the collected material was submitted to content analysis in the following phases: Pre-analysis, in which the organization of the textual material took place; Exploration of the material with coding and classification by the similarity of the nuclei of meaning; Treatment of the results with the constitution of categories and subsequent inference and interpretation ${ }^{(13)}$.

The data organized into categories were exposed in an explanatory chart of the characteristics of stigma. After that, they went through validation by triangulation of researchers. For this, the research team, composed of three PhD researchers, a Ph.D. student, and a master's student, performed the analysis stages individually. Afterward, there was discussion, confrontation, and agreement as to the empirical categories. In the end, the results were interpreted in the light of Erving Goffman's Sociological Theory of Stigma ${ }^{(4)}$, expanded by Link and Phelan ${ }^{(6,8)}$.

\section{RESULTS}

\section{Characterization of the study population}

Twenty-five adults participated in the study, 13 men and 12 women, with ages ranging from 20 to 53 . Black and brown people predominated, with only two participants self-declaring as non-blacks. Eighteen of the respondents had not completed high school, and only two had access to higher education, although incomplete. For the most part, they were low-income individuals, ascertained by the predominance of unemployed, with only two retired due to complications of the SCD. As for the type of SCD, most were affected by sickle cell anemia (SCA), represented by the HbSS type hemoglobinopathy. Besides the pain crisis, the disease presented complications, leg ulcers, and priapism - involuntary and painful erection.

Figure 1 shows the characteristics of stigma found in the interactions that the people with pain and SCD participated in the research established with family members, with people from the general public, and with healthcare workers, and the synthesis of the coping strategies. Thus, the interrelation and convergence of the various components present in stigmatization are exposed in the figure's five columns. In the first column, the "label" informs people's simplistic distinctions and qualifications to classify human differences. In the second column, the "stereotype" manifests the dominant cultural beliefs that link labeled people to undesirable characteristics - the negative stereotypes; the "discredit." The third column exposes the aspect about person discredited; the way how labeled people are placed into distinct categories in order to show some degree of separation between "us" and "them" reveals itself in the fourth column - "estrangement"; and the fifth column "loss of status/ discrimination" records the losses of position and discrimination that lead to unequal results ${ }^{(8)}$.

The four categories that emerged from the data - Stigma in interactions with family members, Stigma in interactions with people in the general public, Stigma in interactions with health care workers, and Stigma coping strategies - are presented below.

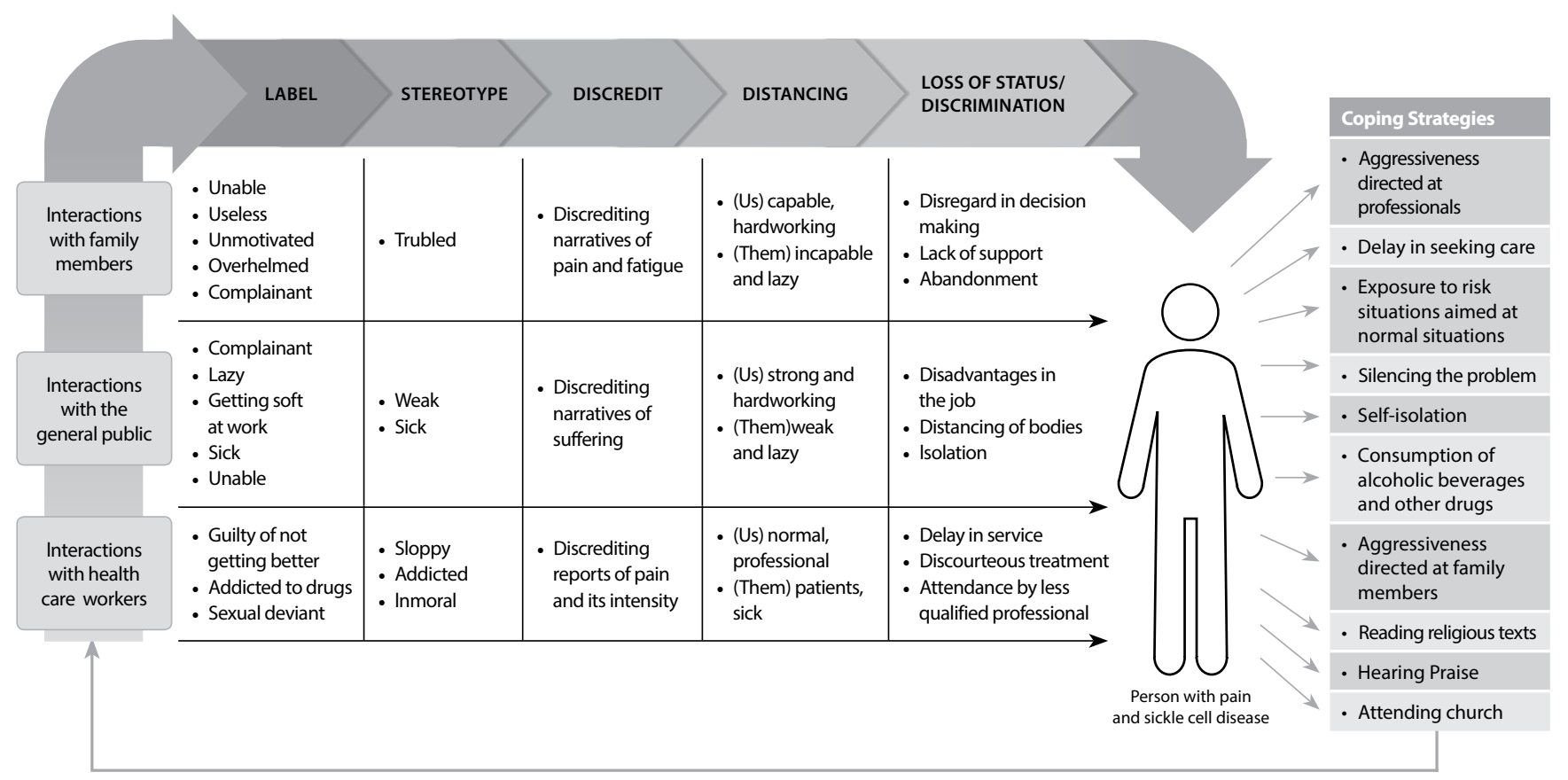

Figure 1 - Characteristics of stigma towards people with pain and sickle cell disease 


\section{Category 1 - Stigma in interactions with family members}

The disqualification of the person with pain and SCD occurred in interactions in public places and experienced in their own homes. This discredit was expressed through attitudes of contempt directed by family members and also by strangers, who used derogatory adjectives to refer to these people. These adjectives were assimilated and formed the self-image, as well as a deteriorated identity. In this way, the person felt misunderstood by the family, who judged them as lazy or uncooperative with the family's daily activities.

They [the family members] never understand that if there is something there that is for everyone to do, if we can't do it, they don't understand. They think we are lazy, that we don't want to do it, that we don't want to help. Then people start complaining over and over like this: "Ah, why don't you do this, don't you do that?"; "It's your fault"; "You have to die soon"; "You're a nuisance, go to the hospital already". (I9)

The family's distancing or abandonment was mentioned, which occurred mainly in situations of physical difficulties that required more attention and protective care, as was the case of painful crises, the most frequent complications of the disease.

I only got angry one time [a painful crisis episode] when my aunt left me there [in the hospital] and didn't want me to come back to her house anymore. She left me in the hospital [crying]. I have already been "kicked out" [expelled] from my stepfather's house. I don't like to remember much. (I8)

Labels such as "careless" and "unaware" linked the sick person's image to that of someone uninterested in collaborating.

\section{Category 2 - Stigma in interactions with the general public}

In social life, it occurred also discredit, and it was common for the person with SCD in the process of chronic pain to be excluded from their social network, besides being labeled as "complainant," "sick," and "incapable" of performing activities practiced by the others.

Given this, to be considered "normal," the sick people felt pressured by their friends, who did not understand their limitations to engage in certain types of activities that stimulated painful processes.

Sometimes a classmate says, "Let's go to the pool and take a bath," and I can't go on these adventures. I can't go, and they don't want to understand, so they take me and throw me into the water. (I3)

They said: "You can't even play ball, you are sick! [...] they [colleagues from the neighborhood] discriminated me saying that I couldn't be on their team, because I was sick, that I felt too much pain. (14)

There are people who think that it is a contagious disease, that sometimes it is a big whoop, that we are not feeling what we feel. It is difficult to find people who know how to deal with the disease. (I15)

Thus, under direct social pressure, sick people tended to submit to the conditions and what could harm their health and well-being to avoid discrimination and alienation from their group. Thus, they were challenged to overcome barriers and limits to prove that they could go further, coming as close as possible to what they considered "normal" to feel accepted.

I remember that there were two teams in the neighborhood. Then, on the team that they said was in the first division, I played once, but they didn't put me on anymore because I felt pain. Then I went to play for the second team. I fought so hard, just out of anger, because they said I was sick. Then we won on penalties. Then I ended up in the hospital. [laughs]. (I4)

Regarding the integration of people with SCD in the labor market, it is important to highlight the explicit incomprehension by employers and coworkers. When they did manage to get into the job market, they were often disqualified and adjectivized in a derogatory and offensive way by their colleagues, who saw them as people pretending to be sick.

I have experienced discrimination at work. I remember I presented two medical certificates, because I felt a lot of pain. The company said: "You must be kidding, every day you present a medical certificate, you are inventing this illness. After seven months, they let me go. They said that I was dragging my feet, that I was lazy, that I was getting soft because I was a registered employee. I worked so hard, and people said I was faking it. (14)

\section{Category 3 - Stigma in interactions with health care workers}

In general, the frequency of visits to health services by people with SCD was high. That happened, among other reasons, to the search for relief from complications such as pain crises. In these moments, health professionals' interactions were marked by questionings about the need to visit the unit, establishing doubt about their pain narratives. From the reception desk, the place of the first contact, several healthcare workers began to make judgments about the patient's decision. Sometimes security guards complained about the frequency with which the individual returned to the service; others, such nurses, and physicians, who worked in the diagnosis, evaluation, and treatment of the painful crisis revealed discredit to the complaints presented. For the participants, the discredit attributed to their narratives resulted from the professionals'lack of knowledge and lack of qualification for the evaluation, diagnosis, and clinical management of pain in SCD.

Several times, he [the security guard] would say, "Boy, every day you with this pain." The nurses would say, "You again? What do you do that you don't get well from this pain? Everybody else gets better and you don't. Who will treat you now is [...]" Because this woman [...] was mean when she gave an injection, you know? That was for me not to go back there anymore. (14)

The pain crises brought patients in front of professionals who raised doubts about the need for emergency care and labeled them as drug addicts, attributing the addicts' stereotype.

The nurse and the doctor said, "Every day this boy is here? We give him medicine; it seems he's addicted to medicine." Then the nurse said, "Could it be that he is used to the effect of the medication?" (I11) 
[...] doctors saying that we are drug addicts, morphine addicts, that the pain is not as much as we say it is and that we go to the clinic just for the morphine, because we are drug addicts, addicts, dependents and that we want that stuff. (I16)

In the interactions that took place in the health services, the perception of stigma was experienced by the perception of racist attitudes. People with SCD perceived themselves as being discriminated against during care because of the disease's marks and skin color. They alleged differentiation in the care of non-black people concerning black people.

They said that I was a baby, that they saw no reason to be moaning. The biggest pain that hurt was discrimination, racism, prejudice. They would say, "You, a healthy black man like that?"I would say, "It hurts a lot." But they didn't believe me. (14)

There was nurse at night, and she discriminated me: "You never get better from this pain, do you? You're just giving us a hard time. It's because you are from Bahia, because you are black. If you were white, you wouldn't do that". (I11)

Racism was perceived in the speeches of professionals who, during care, criticized the person in a pain crisis, devaluating, judging weak, feeble, reinforcing that a black person "must endure pain more," because they believed that black bodies had a higher pain threshold when compared to non-blacks. This belief favored the non-appreciation of the black person's pain, which was often reproached and blamed for their complaints.

\section{Category 4 - Stigma coping strategies}

Faced with the stigma experiences, people adopted several coping strategies, among them, the resistance to return to the healthcare service. Men who experienced episodes of pain and priapism described as shameful the embarrassment experienced when meeting with the healthcare team, which mocked, belittled, and blamed them.

Talking about the marks of stigma caused embarrassment and shame to expose their problem. The fear of moral judgment made them remember their suffering. Thus, individuals preferred to silence the problem and elaborate stories to justify their situation to avoid labels and the recurrence of discrimination.

Many times, I would say: "No, I fell". My aunt would say that it was something else to not expose me, because the female doctor said that I shouldn't be exposed, because it is a delicate subject [pain secondary to priapism], because people may say that I am a "pervert" [...] people don't understand what that is. (I7)

I don't like to talk, no. I feel bad when I talk. I prefer to keep to myself, how much I have been through, how much I have suffered [crying]. (I8)

The sick people moved away from people in their social environment while experiencing the stigma since they became embarrassed by others' stares and questioning their condition. Thus, they preferred to go to places where they supposedly would not be recognized as sick and/or incapable and, therefore, stigmatized. They chose to isolate themselves more and more from people.

I withdraw. I don't fight with anyone, I don't swear at anyone, I don't wish anyone ill, I just walk away. I didn't drink and I started to drink. I didn't like "micareta" music, I didn't fight and then I started to fight. I became desperate because everybody discriminated against me. (E3)

I have fought a lot because of my problems too. I don't like to talk much, no [tears]. (E8)

To perceive oneself as stigmatized could generate anger in sick people, who would then act defensively. That encouraged them to assume aggressive attitudes, neglect self-care, or resort to psychoactive substances to forget or escape problems. The attitude of dodging the problem (e.g., not touching the subject) was a strategic behavior to omit information that could put them in a devaluation position before the other subjects.

Attending churches, listening to music (praises), and reading religious texts to seek empowerment were positive coping strategies mentioned by the participants searching for resilience.

\section{DISCUSSION}

People with SCD experience total pain, in which there is a summation of physical, social, psychological, and spiritual pain, plus the racial experience. Besides, each pain episode elicits feelings of fear, proximity to death, revolt, powerlessness, insecurity, and distrust. In this sense, during the experience of pain, sensitive, emotional, and cultural aspects intersect, deserving to be investigated and considered in the care of the person with $\mathrm{SCD}^{(14)}$.

This study showed that people with pain and SCD experience stigma in various environments - family, social, professional and healthcare settings ${ }^{(15)}$. Other experiences of stigma related to diseases demonstrate that, when noticed, it becomes the primary source for the occurrence of introjected stigma, that is, unconsciously incorporated into the individual's self. In the former case, stigmatizing attitudes or behaviors of others are perceived; in the latter, stigma is self-applied through feelings of self-devaluation, such as self-blame, shame, anger, and regret ${ }^{(7,9,15)}$. Although investigating introjected stigma was not the objective of this study, it became manifested in the participants' narratives.

In the family context, stigma is perceived in the application of derogatory adjectives by family members, in the lack of understanding during episodes of pain, and abandonment attitudes. Studies conducted with stigmatized individuals indicate family members' problems, including rejection and violence by family members, which generates feelings of abandonment associated with the loss of ties with loved ones ${ }^{(16)}$.

The attitudes of family members towards the stigmatized people express a loss of status, asymmetrical relations, and violence, through which inequality is established based on authoritarianism and made explicit by disqualifications, reprimands, embarrassment, humiliation, neglect, and even physical aggression, treating the human being as a non-subject ${ }^{(17)}$.

In social life, the sick people feel excluded from their social network, which considers them sick and incapable. In particular, 
men also feel pressured by friends and even subject themselves to conditions that harm their health and well-being to be accepted and reaffirm their masculinity ${ }^{(18)}$. Thus, the person who suffers stigma because of some disease and its implications may have difficulty relating not only with family but also with friends, neighbors, co-workers, and people from their more distant social environment ${ }^{(1)}$. Therefore, stigma in social life is related to interpersonal violence belonging to the public sphere and permeating social relationships.

This type of interpersonal violence was also experienced by people with SCD who participated in research conducted in Pará. They reported that, in their daily lives, they were often affected by stereotypes, being disqualified at various stages of life and stigmatized. The nicknames revealed characteristics considered peculiar. Thus, among others, the following stand out: "poor little guy," to express feelings of pity about the disease; "weak," because he was seen as anemic; "skeleton" resulted from anorexia; "glass doll" referred to persistent pain crises; "rotten leg" occurred in cases of people with leg ulcers; "sick" indicated unable to work ${ }^{(19)}$.

Depending on the activities they are asked to perform, people with SCD find it challenging to interact with their social network. Swimming in the pool, for example, was reported as a hindrance to social interaction since low-temperature water stimulates pain crises. Also, patients are constantly reminded of self-care responsibilities and avoid baths of this nature ${ }^{(20)}$. Thus, avoiding river and pool baths or even staying with wet clothes on beaches because of the cold were self-care measures adopted by the participants to avoid vaso occlusive crises, as corroborated in the literature ${ }^{(19)}$. However, some preferred to submit themselves to conditions that tended to trigger painful crises to be accepted by their groups of friends.

Some people who suffer stigma may develop strategies to overcome the barriers imposed by society to prove their ability to go beyond the expectations pre-defined by common sense ${ }^{(4)}$. Therefore, individuals aim to get as close as possible to the standard of "normality" to be accepted by their social network members. However, when participating in activities that challenge physical capacity, they adopt a confrontation that puts their lives at risk.

Regarding work activities, the participants of this study also reported that pain sometimes prevented them from working. Besides, the episodes of pain in the work environment led to offensive and pejorative adjectives. The unpredictability and chronicity of the pain crises caused by SCD make it difficult not only to get a job but also to keep it. Employers and coworkers see fatigue, tiredness, and indisposition as unwillingness and irresponsibility ${ }^{(21-22)}$.

A study showed that the disease's ignorance reflects stigma in the workplace, and people with SCD are labeled as lazy and liars, and it is common to dismiss the worker ${ }^{(22)}$. The label used to describe the person motivates other subjects to desire social distance $^{(23)}$.

In the case of men with pain and SCD, the most prevalent gender among the participants of this study, to stop working is a reason for frustration since it is an aspect related not only to physical strength but also to the fact of being socially considered the head and responsible for the maintenance of the family. Such frustration accompanies the fear of isolation, abandonment, and loss of the social and economic role exercised within the family ${ }^{(24)}$.
Attitudes of disrespect, subjection, annoyance, or embarrassment, mainly when healthcare professionals cause the discriminatory harassment, may reflect incorrect or limited information about the disease. The lack of qualification to care for the person with SCD in its complications results from the disease's invisibility in professional training curricula(19-25).

All participants pointed out having their pain devalued and poorly evaluated and the delay in care during painful crises. A study indicates that the prolonged wait for pain management favors this symptom's worsening ${ }^{(25)}$. The devaluation of pain even comes from the professionals who are usually responsible for the reception, reception, and administration of medicines, as highlighted in a study ${ }^{(26)}$.

Research indicates that pain is described by people with SCD as "persistent," "always present," "consistent," and "recurrent"; a constant pain that can cause psychological and psychopathological changes, such as depression, anxiety, and personality disorders. Thus, the pain can lead the person to unbalance, make them nervous, aggressive, not knowing what to do, requesting medications from health professionals all the time ${ }^{(27-28)}$.

Stigmatizers are in positions in which they can subordinate, regulate or exclude others based on power ${ }^{(8)}$. In the power relations established between healthcare workers and people in illness, there is an expectation of professionals to discipline and docile the bodies. The more the user complains about more drugs or criticizes the professional's action for not giving them measures capable of reducing suffering, the more they are labeled and discriminated against ${ }^{(29)}$. In this study, people with SCD revealed receiving discourteous and negligent treatment in painful crises. Receiving treatment for pain relief is a human right and must be considered an ethical issue, not only a clinical one. That said, healthcare professionals must face pain crisis as a priority in people with SCD at health units ${ }^{(30)}$.

The intersection of stigma with structural racism, evidenced in this study, reveals the collective failure of health institutions to offer appropriate and professional service to people based on their color, culture, and ethnicity ${ }^{(31)}$. In SCD, stigma is crossed by racism, mainly because the majority of the population with $S C D$ is black and belongs to the lowest strata of society. So, stigma leads to the intersection of social depreciation marks, undermining both the sick individual's interaction with health professionals and the quality of care offered ${ }^{(26)}$.

In the present study, one participant recalls being asked about pain because he was black and apparently strong. The idea that black people have a greater ability to withstand pain than the threshold of people with non-black skin is still widespread in health services nowadays. A study on the experience of racial and class prejudice in the SCD verified the existence of this myth among healthcare professionals ${ }^{(32)}$. This misconception reveals itself when, during a pain crisis caused by the disease, the professionals who should provide adequate and humanized care claim that the person can endure pain without analgesia, using the color of their skin as justification ${ }^{(26,32)}$

The patient's attribution for the repeated pain crises emerged from the statements, indicating the "guilt" as a characteristic of stigma, which, consequently, grounds discriminatory attitudes. Contemporary sociologists affirm that the conception of pain, 
which, in modernity, was seen as a deserved punishment for some reprovable conduct, is still deeply rooted in the current discourse. The result is pain conformism and trivialization by healthcare professionals of the pain, referred by the sick person, evidencing the stigma of the person with pain $^{(32-33)}$

Men with SCD suffer discrimination and prejudice when they suffer a priapism crisis, one of its complications. Many blame the patient for confusing it with penile erection related to sexual desire, so they treat him with disrespect, labeling, and excessive exposure, generating embarrassment and shame ${ }^{(22,34)}$.

In the face of visible marks, such as wounds and jaundice, for example, discrimination is derived from appearance. In pain, there is no visibility. Discredit focuses on what the subject reports feeling. In this sense, while they try to hide visible marks, such as wounds and yellowish eyes, in pain events, there will be an effort to try to prove that the pain is real so that the professionals validate their narratives ${ }^{(19)}$

People affected by stigmatizing diseases use information control techniques to hide or eliminate marks that become symbols of stigma. Thus, subjects tend to manipulate information about the disease to control or avoid a potentially stigmatizing situation ${ }^{(33)}$. In SCD, silencing about the disease does not help access care since the approach to the person with SCD can occur inappropriately. Therefore, people should be encouraged to inform having SCD whenever they seek professional help.

In the group studied, for fear of anticipated discrimination, the actions to control stigma implied managing the pain at home and delaying as much as possible the search for health services. So, they maintained isolation as long as the pain did not reach intolerable levels. The attitude of delaying the search for emergency services to control pain and other complications signals that the sick people have already introjected the stigma. By assuming the stereotypes, they experience the role of anticipated stigma, that is, the expectation of being negatively stereotyped or discriminated against in future encounters for having $\mathrm{SCD}^{(35)}$. The person adopts social isolation, which represents the lack of social interaction, contact, or communication, identified by the psychological, social, or physical distancing of the ill person from their relationship network ${ }^{(36-37)}$.

When perceiving themselves as stigmatized, the participants experienced outrage, which led them to act aggressively or resort to the consumption of psychoactive substances. The stigmatized person oscillates between withdrawal and aggressiveness, for not meeting rigid standards of normality imposed by society, tending to consider themselves unworthy, incomplete, and inferior ${ }^{(7,38)}$.

Among the motivations for alcohol use, one can highlight the attempt to escape from problems and forget them or use it as an aid to deal with unpleasant situations ${ }^{(39)}$. These statements confirm the findings of this study, in which it was possible to observe that the stigma of the person with pain and SCD was the starting point for alcohol abuse.

Positive coping was evidenced by the participants' approach to religious practices. They reported using services, readings, and listening to gospel music to overcome the discrimination's adversities. Studies involving the black population with SCD have shown that, in addition to expanding the social support network ${ }^{(40)}$ and promoting psychological well-being, the relationship with the divine and with religious practices is a protective factor against racial stigma ${ }^{(41)}$.

\section{Study limitations}

Among the study's limitations, we highlight the impossibility of deepening the debate on the intersection of the personal, social, and ego elements to understand the deteriorated identity and structural stigma levels. Besides, we interviewed people who were mostly users of public services, with low education levels, and blacks who also experienced racism. In this sense, this study's results cannot be generalized since the interaction processes could suffer influence by class and race/color differentials.

\section{Contributions to the Fields of Nursing, Health or Public Policy}

The results of this study highlight the need for greater dissemination of knowledge about SCD in the public sphere and professional training and understanding of the social ramifications on sick individuals to prevent discriminatory attitudes that increase their vulnerability.

By recognizing the characteristics of stigma, healthcare workers can adopt a self-vigilant posture about the careless attitudes operated by stigma during interactions in the service units. We recommend further studies and interventions that can explore stigma from the perspective of stigmatizers as starting points for addressing stigma directed towards sick people and reducing its consequences.

\section{FINAL CONSIDERATIONS}

People with pain and SCD experience the stigma in various interactions: family circle, work environment, or health care. Those with SCD suffer violence, are disqualified, diminished, adjectivized with pejorative terms, and victims of abandonment and mistreatment. That translates into deficits in disease management, low adherence to self-care measures, and difficulties in access to treatment, guidance with quality, and preventive and prophylactic actions for complications that impact individuals' quality of life.

The multi-professional team, while providing necessary assistance and enabling access to quality guidance, contribute to overcome the invisibility of the disease, clarify doubts, demystify beliefs that place the patient in a condition of depreciation, as well as sensitize the family and society about the physical and psycho-emotional limitations that pain produces in the person with SCD.

In the context of health services, it is urgent to qualify professionals about the SCD in the various levels of care so that they recognize pain as one of the most severe complications of the disease so that they can evaluate and treat the episode of pain, understanding that it constitutes a clinical emergency. Thus, during the interaction with the patients, it is essential to prevail the question, "What can I do to help you not feel so much pain?"

\section{FUNDING}

Conselho Nacional de Desenvolvimento Científico e Tecnológico (CNPq), PDE 203809/2018-1.

\section{ACKNOWLEDGMENT}

Associação Feirense de Pessoas com Doença Falciforme, Associação Baiana de Pessoas com Doença Falciforme, College of Nursing - University of South Carolina. 


\section{REFERENCES}

1. Brennan-Cook J, Bonnabeau E, Aponte R, Augustin C, Tanabe P. Barriers to care for persons with sickle cell disease: the case manager's opportunity to improve patient outcomes. Prof Case Manag. 2018;23(4):213-9. https://doi.org/10.1097/NCM.0000000000000260

2. Tran H, Gupta M, Gupta K. Targeting novel mechanisms of pain in sickle cell disease. Hematology Am Soc Hematol Educ Program. 2017;2017(1):546-55. https://doi.org/10.1182/asheducation-2017.1.546

3. Vgontzas A, Charleston L 4th, Robbins MS. Headache and facial pain in sickle cell disease. Curr Pain Headache Rep. 2016;20(3):20. https:// doi.org/10.1007/s11916-016-0546-z

4. Goffman E. Estigma: notas sobre a manipulação da identidade deteriorada. 4a ed. Rio de Janeiro: LTC; 1988.

5. Volz PM, Tomasi E, Bruck NRV, Saes MO, Nunes BP, Duro SMS, et al. A inclusão social pelo trabalho no processo de minimização do estigma social pela doença. Saúde Soc. 2015;24(3):877-86. https://doi.org/10.1590/S0104-12902015130040

6. Lucas JW, Phelan JC. Stigma and Status: The Interrelation of Two Theoretical Perspectives. Soc Psychol Q. 2012;75(4):310-33. https://doi. org/10.1177/0190272512459968

7. Bulgin D, Tanabe P, Jenerette C. Stigma of sickle cell disease: a systematic review. Issues Ment Health Nurs. 2018;39(8):675-86. https://doi.org $/ 10.1080 / 01612840.2018 .1443530$

8. Phelan JC, Lucas JW, Ridgeway CL, Taylor CJ. Stigma, status, and population health. Soc Sci Med. 2014;103:15-23. https://doi.org/10.1016/j. socscimed.2013.10.00

9. Nascimento LA, Leão A. Estigma social e estigma internalizado: a voz das pessoas com transtorno mental e os enfrentamentos necessários. Hist Cienc Saude-Manguinhos. 2019;26(1):103-21. https://doi.org/10.1590/s0104-59702019000100007

10. Tong A, Sainsbury P, Craig J. Consolidated criteria for reporting qualitative research (COREQ): a 32-item checklist for interviews and focus groups. Int J Health Care Qual Assur. 2007;19(6):349-57. https://doi.org/10.1093/intqhc/mzm042

11. Peters K, Halcomb E. Interviews in qualitative research. Nurse Res. 2015;22(4):6-7. https://doi.org/10.7748/nr.22.4.6.s2

12. Fontanella BJB, Luchesi BM, Saidel MGB, Ricas J, Turato ER, Melo DG. Amostragem em pesquisas qualitativas: proposta de procedimentos para constatar saturação teórica. Cad Saúde Pública. 2011;27(2):389-94. https://doi.org/10.1590/S0102-311X2011000200020

13. Erlingsson C, Brysiewicz P. A hands-on guide to doing content analysis. Afr J Emerg Med. 2017;7(3):93-9. https://doi.org/10.1016/j.afjem.2017.08.001

14. Ministério da Saúde (BR). Secretaria de Atenção à Saúde. Departamento de Atenção Hospitalar e de Urgência. Doença falciforme: enfermagem nas urgências e emergências: a arte de cuidar [Internet]. Brasília; 2014 [cited 2016 Oct 30]. 76 p. Available from: http:// biblioteca.cofen.gov.br/wp-content/uploads/2015/06/doenca_falciforme_enfermagem_urgencias_emergencias.pdf

15. Jenerette CM, Brewer C. Health related stigma in young adults with sickle cell disease. J Natl Med Assoc. 2010;102(11):1050-5. https://doi. org/10.1016/s0027-9684(15)30732-x

16. Hamann HA, Ostroff JS, Marks EG, Gerber DE, Schiller JH, Lee SJ. Stigma among patients with lung cancer: a patient-reported measurement model. Psychooncol. 2014;23(1):81-92. https://doi.org/10.1002/pon.3371

17. Nunes $M$, Torrenté $M$. Stigma and violence in dealing with madness: narratives from psychosocial care centers in Bahia and Sergipe, Northeastern Brazil. Rev Saúde Pública. 2009;43(suppl 1):101-8. https://doi.org/10.1590/s0034-89102009000800015

18. Couto MT, Dantas SMV. Gender, masculinities, and health in review: production of the field in the journal Saúde e Sociedade. Saude Soc. 2016;25(4):857-68. https://doi.org/10.1590/s0104-12902016172308

19. Ezenwa MO, Molokie RE, Wilkie DJ, Suarez ML, Yao Y. Perceived injustice predicts stress and pain in adults with sickle cell disease. Pain Manag Nurs. 2015;16(3):294-306. https://doi.org/10.1016/j.pmn.2014.08.004

20. Costa DO, Araújo FA, Xavier ASG, Araújo LS, Silva UB, Santos EA, et al. Self-care of men with priapism and sickle cell disease. Rev Bras Enferm. 2018;71(5):2418-24. https://doi.org/10.1590/0034-7167-2017-0464

21. Blake A, Asnani V, Leger RR, Harris J, Odesina V, Hemmings DL, et al. Stigma and illness uncertainty: adding to the burden of sickle cell disease. Hematology. 2018;23(2):122-30. https://doi.org/10.1080/10245332.2017.1359898

22. Ola BA, Yates SJ, Dyson SM. Living with sickle cell disease and depression in Lagos, Nigeria: a mixed methods study. Soc Sci Med. 2016;161:27-36. https://doi.org/10.1016/j.socscimed.2016.05.029

23. Link BG, Phelan JC. Conceptualizing Stigma. Annu Rev Sociol. 2001;27:363-85. https://doi.org/ 10.1146/annurev.soc.27.1.363

24. Cordeiro RC, Ferreira SL, Santos AC. The illness of women and men with sickle cell disease: a Grounded Theory study. Rev Latino-Am Enfermagem. 2015;23(6):1113-20. https://doi.org/ 10.1590/0104-1169.0594.2656

25. Wesley KM, Zhao M, Carroll Y, Porter JS. Caregiver perspectives of stigma associated with sickle cell disease in adolescents. J Pediatr Nurs. 2016;31(1):55-63. https://doi.org/10.1016/j.pedn.2015.09.011

26. Matthie N, Jenerette C. Sickle cell disease in adults: developing an appropriate care plan. Clin J Oncol Nurs. 2015;19(5):562-7. https://doi. org/10.1188/15.CJON.562-567 
27. Coleman B, Ellis-Caird H, McGowan J, Benjamin MJ. How sickle cell disease patients experience, understand and explain their pain: an interpretative phenomenological analysis study. Br J Health Psychol. 2016;21(1):190-203. https://doi.org/10.1111/bjhp.12157

28. Goldstein-Leever A, Peugh JL, Quinn CT, Crosby LE. Disease self-efficacy and health-related quality of life in adolescents with sickle cell disease. J Pediatr Hematol Oncol. 2018;42(2):141-4. https://doi.org/10.1097/MPH.0000000000001363

29. Carvalho EMMS, Espírito Santo FH, Izidoro C, Santos MLSC, Santos RB. Nursing care to people suffering with sickle cell disease in emergency unit. Ciênc Cuid Saúde. 2016;15(2):328-35. https://doi.org/10.4025/cienccuidsaude.v15i2.29262

30. Silveira NB, Silveira RS, Avila LI, Gonçalvez NGC, Lunard VL, Enderle CF. Therapeutic nursing procedures in the context of pain: patient's perception. Enferm Foco. 2016;7(1):61-5. https://doi.org/10.21675/2357-707X.2016.v7.n1.669

31. Sampaio EO. Racismo Institucional: desenvolvimento social e políticas públicas de caráter afirmativo no Brasil. Interações [Internet]. 2003 [cited 2019 Sep 13];4(6):77-83. Available from: http://www.interacoes.ucdb.br/article/view/561/598

32. Collier R. “Complainers, malingerers and drug-seekers" - the stigma of living with chronic pain. CMAJ. 2018;190(7):E204-5. https://doi. org/10.1503/cmaj.109-5553

33. Peltzer K, Pengpid S. Anticipated stigma in chronic illness patients in Cambodia, Myanmar and Vietnam. Nagoya J Med Sci. 2016;78(4):42335. https://doi.org/10.18999/nagjms.78.4.423

34. Maia HAAS, Alvaia MA, Carneiro JM, Xavier ASG, Bessa Jr J, Carvalho ESS. Acesso de homens com doença falciforme e priapismo nos serviços de emergência. BrJP. 2019;2(1):20-6. https://doi.org/10.5935/2595-0118.20190005

35. Bediako SM, Lanzkron S, Diener-West M, Onojobi G, Beach MC, Haywood Jr C. The measure of sickle cell stigma: initial findings from the improving patient outcomes through respect and trust study. J Health Psychol. 2016;21(5):808-20. https://doi. org/10.1177/1359105314539530

36. Santos WA, Fuly PSC, Santos MLSC, Souto MD, Reis CM, Castro MCF. Evaluation of social isolation among patients with odor in neoplastic wounds: integration review. Rev Enferm UFPE. 2017;11(supl 3):1495-503. https://doi.org/10.5205/reuol.10263-91568-1-RV.1103sup201723

37. Ouro FL, Sousa AR, Moreira WC, Santos WN, Carvalho ESS, Pereira Á. Impacts on sexuality of men living with chronic wounds: integrative review. Rev Enferm UFPE. 2017;11(2):675-90. https://doi.org/10.5205/1981-8963-v11i2a11987p675-690-2017

38. Müller T. Stigma, the moral career of a concept: some notes on emotions, agency, teflon stigma, and marginalizing stigma. Symb Interact. 2020;43(1):3-20. https://doi.org/10.1002/symb.473

39. Silva RA, Menezes JA. Reflexões sobre o uso de álcool entre jovens quilombolas. Psicol Soc. 2016;28(1):84-93. https://doi. org/10.1590/1807-03102015v28n1p084

40. Gomes MV, Xavier ASG, Carvalho ESS, Cordeiro RC, Ferreira SL, Morbeck AD. "Waiting for a miracle": Spirituality/Religiosity in coping with sickle cell disease. Rev Bras Enferm. 2019;72(6):1554-61. https://doi.org/10.1590/0034-7167-2018-0635

41. Butler-Barnes ST, Martin PP, Hope EC, Copeland-Linder N, Scott ML. Religiosity and coping: racial stigma and psychological well-being among African American girls. J Relig Health. 2018;57(5):1980-95. https://doi.org/10.1007/s10943-018-0644-9 